\title{
Chronic Treatment with Anti-bipolar Drugs Down-Regulates Gene Expression of TRPC1 in Neurones
}

\author{
Ting Du ${ }^{1}$, Yan Rong ${ }^{1}$, Rui Feng ${ }^{1}$, Alexei Verkhratsky ${ }^{2,3}$ and Liang Peng ${ }^{1 *}$ \\ 1 Laboratory of Metabolic Brain Diseases, Institute of Metabolic Disease Research and Drug Development, China Medical \\ University, Shenyang, China, ${ }^{2}$ Faculty of Life Sciences, The University of Manchester, Manchester, UK, ${ }^{3}$ Achucarro Center \\ for Neuroscience, Basque Foundation for Science, Bilbao, Spain
}

\section{OPEN ACCESS}

Edited by:

Francesco Moccia, University of Pavia, Italy

Reviewed by:

Francesco Lodola, Fondazione Istituto Italiano di Technologia, Italy Juan Antonio Rosado Dionisio, University of Extremadura, Spain

${ }^{*}$ Correspondence: Liang Peng sharkfin039@yahoo.com

Received: 08 October 2016 Accepted: 22 December 2016

Published: 10 January 2017

Citation:

Du $T$, Rong $Y$, Feng $R$, Verkhratsky $A$ and Peng L (2017) Chronic Treatment

with Anti-bipolar Drugs

Down-Regulates Gene Expression of TRPC1 in Neurones.

Front. Cell. Neurosci. 10:305. doi: 10.3389/fncel.2016.00305
In the brain, TRPC1 channels are abundantly expressed in neurones virtually in all regions; these proteins function as receptor-activated ion channels and are implicated in numerous processes, being specifically important for neurogenesis. Primary cultures of mouse cerebellar granule cell, cerebral cortical neurones, and freshly isolated neurones from in vivo brains were used to study effects of chronic treatment with anti-bipolar drugs [carbamazepine (CBZ), lithium salts and valproic acid] on gene expression of TRPC1. Expression of TRPC1 mRNA was identified with reverse transcription-polymerase chain reaction, whereas protein content was determined by Western blotting. Store-operated plasmalemmal $\mathrm{Ca}^{2+}$ entry (SOCE) was measured with fura-2 based microfluorimetry. Chronic treatment with each of the three drugs down-regulated mRNA and protein expression in cultured cerebellar granule cells in a time- and concentration-dependent manner. Similar effect was also observed in cultured cerebral cortical neurones treated with CBZ, lithium salts and valproic acid and in freshly isolated neurones from the brains of CBZ-treated animals. The amplitude of SOCE was substantially decreased in cerebellar granule cells chronically treated with each of the three drugs. Our findings indicate that down-regulation of TRPC1 gene expression and function in neurones may be one of the mechanisms of anti-bipolar drugs action.

Keywords: neurone, bipolar disorder, carbamazepine, lithium salts, valproic acid, TRPC1 channels, SOCE

\section{INTRODUCTION}

Bipolar disorder (BD) is a common, devastating and chronic mental disease that affects $1-3 \%$ of the population (Goodwin and Jamison, 2007). Carbamazepine (CBZ), lithium salts $\left(\mathrm{Li}^{+}\right)$, and valproic acid (VPA) are the three classical anti-bipolar drugs. However, despite being in clinical use for several decades, the mechanisms underlying their therapeutic effects remain elusive. Given CBZ, $\mathrm{Li}^{+}$, and VPA share no similarity in chemical structures, revealing downstream effects of all three drugs is important for further understanding drug targets and the pathophysiology of the disease. We have found several genes that are regulated by chronic treatment with anti-bipolar drugs in astrocytes (for review, see Peng et al., 2016). These includes down-regulation of gene expression of glutamate kainate receptor GluK2 (Li et al., 2009), the $\mathrm{Ca}^{2+}$-dependent phospholipase $\mathrm{A}_{2}$ (Li et al., 2007) and transient receptor potential channel 1 (TRPC1); a cation channel, which in astroglia is activated by ER store depletion and contributes to the store-operated $\mathrm{Ca}^{2+}$ entry, SOCE (Yan et al., 2013). 
TRPC1 channels are abundantly expressed in all regions of the brain, including cortex, hippocampus, cerebellum, forebrain, brain stem and basal ganglia (Riccio et al., 2002; Martorana et al., 2006; Narayanan et al., 2008 and see Vennekens et al., 2012 for comprehensive review). In the early neurogenesis TRPC1 channels have been proven to be critical, because they control proliferation of adult neural progenitor cell, and genetic deletion of TRPC1 significantly reduced proliferation rate of these progenitors. Importantly the contribution of TRPC1 to regulation of proliferation was directly linked to TRPC1mediated SOCE (Li et al., 2012). In addition TRPC1 (together with TRPC5 and TRPC6) regulate neurite extension, most likely through fine tuning $\mathrm{Ca}^{2+}$ signals in the growth cone (Vennekens et al., 2012).

We are therefore, interested in whether canonical antibipolar drugs have effect on TRPC1 gene expression in neurones. In the present paper, we report experiments on primary cultures of mouse cerebellar granule neurones, cerebral cortical neurones, and freshly isolated neurones from transgenic mice expressing a fluorescent neurone-specific marker used for fluorescence-activated sorting (FACS). Cerebellar granule cells represent a well-established, well-differentiated model for studying glutamatergic signaling (Gallo et al., 1987; Marini et al., 1989; Peng et al., 1991; Bak et al., 2003); granule neurones express NMDA, AMPA and metabotropic glutamate receptors, and they are vulnerable to excitotoxic insults (Condorelli et al., 1993; Lavreysen et al., 2005). Cerebral cortical neurones are GABAergic and also sensitive to glutamate excitotoxicity mediated by NMDA receptors (Chuang et al., 2002), whereas in experiments in vivo analysis was mainly restricted to large projection neurones which express Thy1 promoter. We studied: (i) effects of chronic treatment with anti-bipolar drugs on mRNA and protein expression of TRPC1 in primary cultures of cerebellar granule neurones; (ii) effects of chronic treatment with anti-bipolar drugs on mRNA and protein expression of TRPC1 in primary cultures of cerebral cortical neurones; (iii) expression of TRPC1 mRNA in FACSisolated neurones from animals treated with daily injections of $\mathrm{CBZ}$, and (iv) effects of chronic treatment with anti-bipolar drugs on SOCE in primary cultures of cerebellar granule cells.

\section{MATERIALS AND METHODS}

\section{Animals}

Male B6.Cg-Tg(Thy1-YFPH)2Jrs/J mice (from The Jackson Laboratory, Bar Harbor, ME, USA), weighing 20-25 g were housed in cages on a $12 \mathrm{~h}$ light/dark cycle in a temperaturecontrolled $\left(23-25^{\circ} \mathrm{C}\right)$ colony room with free access to food and water. These transgenic mice express fluorescent neuronespecific marker, allowing fluorescence-activated sorting of specified cell fractions, although it should be emphasized that Thyl is mainly a marker of large projection neurones rather than a general neuronal marker (Feng et al., 2000; Seki et al., 2002). All experiments were carried out in accordance with the USA National Institute of Health Guide for the Care and Use of Laboratory Animals (NIH Publications No. 80-23) revised 1978, and all experimental protocols were approved by the Institutional Animal Care and Use Committee of China Medical University.

\section{Cell Cultures}

Cerebellar granule cells were cultured as previously described (Peng et al., 1991) with minor modifications. Briefly, 7-day-old mouse pups were rapidly decapitated and the brains taken out. The cerebella were aseptically separated from the remainder of the brain, and after removal of the meninges, the tissue was cut into cubes of $-0.4 \mathrm{~mm}$ side dimensions, exposed to trypsin in a $\mathrm{Ca}^{2+} / \mathrm{Mg}^{2+}$-free salt solution, reintroduced into tissue culture medium, passed through nylon sieves and seeded into polylysine coated standard 35-mm tissue culture dishes (Wuzhou Medical Plastic Factory, Zhejiang, China), using one cerebellum per culture dish. The cultures were grown in Dulbecco's medium in which the glucose concentration was increased to $30 \mathrm{mM}$ and the $\mathrm{K}^{+}$concentration to $24.5 \mathrm{mM}$, the glutamine concentration was decreased to $0.8 \mathrm{mM}$ and $7 \%$ horse serum was added. The elevation of the $\mathrm{K}^{+}$concentration is necessary for normal development of the cells (Gallo et al., 1987) and more specifically for normal dendritic development and for release of transmitter glutamate (Peng et al., 1991). After 2 days, cytosine arabinoside was added to the medium to a final concentration of $40 \mu \mathrm{M}$ to curtail astrocytes growth. The cells were used at the age of 7-8 days at which time they have reached maturity (Peng et al., 1991).

Cerebral cortical neurones were prepared by a similar method as the cerebellar granule neurones (Hertz et al., 1989) except that cortical hemispheres from 14-day-old mouse embryos were used as the source of the cultures and that the cultures were grown in normal tissue culture medium with $5.4 \mathrm{mM} \mathrm{K}^{+}$and $2 \mathrm{mM}$ glutamine. The cultures were used at 8-10 days of age when they have developed characteristics of mature cortical interneurones (Schousboe and Hertz, 1987).

\section{Drug Treatment}

Adult mice were daily injected intraperitoneally with CBZ [25 mg/kg/d dissolved in $0.9 \% \mathrm{NaCl}$ (Rao et al., 2007)] or saline for 3 or 7 days. Three days after plating primary cultures of cerebellar granule cells and cerebral cortical neurones were treated with CBZ, lithium carbonate or VPA for either 3 or 7 days.

\section{Preparation of Freshly Isolated Cells}

Immediately after decapitation, cerebral hemispheres (without olfactory bulbs and hippocampi) were removed. The remaining parts of the brains were placed in cold Hanks buffer containing glutamate receptor antagonists $(3 \mu \mathrm{M}$ DNQX and $100 \mu \mathrm{M}$ APV), cut into small pieces, and digested with $8 \mathrm{U} / \mathrm{ml}$ papain in $\mathrm{Ca}^{2+} / \mathrm{Mg}^{2+}$-free PIPES/cysteine buffer, $\mathrm{pH} 7.4$, for $1 \mathrm{~h}$ at $37^{\circ} \mathrm{C}$ in a humidified atmosphere of $\mathrm{CO}_{2}$ /air (5:95\%). After one wash, the tissue was further digested with $40 \mathrm{U} / \mathrm{ml}$ DNase I in $\mathrm{Mg}^{2+}$-containing minimum essential medium (MEM) with $1 \%$ bovine serum albumin (BSA) for $15 \mathrm{~min}$ at $37^{\circ} \mathrm{C}$ in a humidified atmosphere of $\mathrm{CO}_{2} /$ air (5:95\%). It was then carefully triturated in cold MEM with 1\% BSA, and centrifuged over a 
90\% Percoll gradient, followed by collection of all cells below and including the lipid layer. This suspension was further diluted five times, with MEM containing 1\% BSA, and centrifuged to collect the pellet. Immediately thereafter, the cells were resuspended in cold MEM with $1 \%$ BSA and $4 \mu \mathrm{g} / \mathrm{ml}$ propidium iodide and sorted by FACS using the BD FACSAria Cell Sorting System (35 psi sheath pressure, FACSDiva software S/W 2.2.1; BD Biosciences, San José, CA, USA) as described by Lovatt et al. (2007). YFP were excited by a $488 \mathrm{~nm}$ laser, and emissions were collected by $530 \mathrm{~nm}$ discrimination filters. Since a relatively small amount of cells was obtained following FACSseparation we performed only mRNA detection. Cell identity and purity were verified by mRNA expression of cell markers of astrocytes, neurones and oligodendrocytes, analyzed by reversetranscription polymerase chain reaction (RT-PCR), in astrocytic and neuronal cell preparations. As shown by Fu et al., 2012 there is no contamination with neuronal or oligodendrocytic genes in the samples of astrocytes or of astrocytic or oligodendrocytic genes in the neuronal samples.

\section{Reverse Transcription-Polymerase Chain Reaction (RT-PCR)}

For determination of mRNA expression by RT-PCR, a cell suspension was prepared by discarding the culture medium, adding Trizol to cultures on ice, and scraping the cells off the culture dish. The RNA pellet was precipitated with isopropanol, washed with $70 \%$ ethanol, and dissolved in $10 \mu \mathrm{l}$ sterile, distilled water, and an aliquot was used for determination of the amount of RNA (Kong et al., 2002).

Reverse-transcription was initiated by a 5 min-incubation at $65^{\circ} \mathrm{C}$ of $1 \mu \mathrm{g}$ RNA extract with Random Hexamer at a final concentration of $12.5 \mathrm{ng} / \mathrm{l}$ and deoxy-ribonucleoside triphosphates (dNTPs) at a final concentration of $0.5 \mathrm{mM}$. The mixture was rapidly chilled on ice and briefly spun, and $4 \mu \mathrm{l} 5 \times$ First-Strand Buffer, $2 \mu 10.1 \mathrm{M}$ dithiotreitol and $1 \mu \mathrm{l}$ RNaseOUT Recombinant RNase Inhibitor ( $40 \mathrm{U} / \mu \mathrm{l})$ were added. After the mixture had been incubated at $42^{\circ} \mathrm{C}$ for $2 \mathrm{~min}, 1 \mu \mathrm{l}(200 \mathrm{U})$ of Superscript II was added, and the incubation at $42^{\circ} \mathrm{C}$ continued for another $50 \mathrm{~min}$. Subsequently, the reaction was inactivated by heating to $70^{\circ} \mathrm{C}$ for $15 \mathrm{~min}$, and the mixture was chilled and briefly centrifuged.

Polymerase chain reaction (PCR) amplification was performed in a Robocycler thermocycler with $0.2 \mu \mathrm{M}$ of sense or antisense and $0.375 \mathrm{U}$ of Taq polymerase for TRPC1 (forward, CCTTCTCATACTGTGGATTATTG; reverse, GTACCAGAACAGAGCAAAGCA) (Ng et al., 2009), and for TATA box-binding protein (TBP), used as a housekeeping gene (forward, CCACGGACAACTGCGTTGAT; reverse, GGCTCATAGCTACTGAACTG) (el-Marjou et al., 2000), designed and purchased form Sangon Company (Shanghai, China). Initially the template was denatured by heating to $94^{\circ} \mathrm{C}$ for $2 \mathrm{~min}$, followed by $2.5 \mathrm{~min}$ amplification cycles, each consisting of two 45-s periods and one 60-s period, the first at $94^{\circ} \mathrm{C}$, the second at $58^{\circ} \mathrm{C}$ for TRPC 1 and at $55^{\circ} \mathrm{C}$ for TBP, and the third at $72^{\circ} \mathrm{C}$. The final step was extension at $72^{\circ} \mathrm{C}$ for $10 \mathrm{~min}$. The PCR products were separated by $1 \%$ agarose gel electrophoresis, stained with $0.5 \mu \mathrm{g} / \mathrm{ml}$ ethidium bromide, and captured by Fluorchem 5500 (Alpha Innotech Corporation, San Leandro, CA, USA).

\section{Western Blotting}

Protein content was determined by the Lowry method (Lowry et al., 1951), using BSA as the standard. Samples containing $100 \mu \mathrm{g}$ protein for TRPC1 or $20 \mu \mathrm{g}$ for $\beta$-actin were applied on slab gels of $10 \%$ polyacrylamide and electrophoresed. After transfer to polyvinylidene fluoride (PVDF) membranes, the samples were blocked by $5 \%$ skim milk powder in TBS-T (30 mM Tris- $\mathrm{HCl}, 125 \mathrm{mM} \mathrm{NaCl}, 0.1 \%$ Tween 20) for $1 \mathrm{~h}$. The PVDF membranes were incubated with the first antibody, specific to TRPC1 overnight at $4^{\circ} \mathrm{C}$, or $\beta$-actin for $2 \mathrm{~h}$ at room temperature. After washing, the blots were incubated with peroxidase-conjugated affinity-purified goat-anti-mouse or goatanti-rabbit horseradish antibody for $2 \mathrm{~h}$. Staining was visualized by ECL detection reagents. Digital images obtained using GelImaging System (Tanon, 4200, Shanghai). Optical density for each band was assessed using the Window Alpha-Ease TM FC 32-bit software.

\section{Monitoring of Intracellular $\mathrm{Ca}^{2+}$ Concentration}

For $\left[\mathrm{Ca}^{2+}\right]_{i}$ recordings an Olympus IX71 live cell imaging fluorescence microscope (Tokyo, Japan) was used to monitor fluorescence intensity of Fura-2 loaded cultured neurones. For Fura-2/AM loading the growth medium was replaced with saline solution $\left(137 \mathrm{mM} \mathrm{NaCl}, 5 \mathrm{mM} \mathrm{KCl}, 0.44 \mathrm{mM} \mathrm{KH}_{2} \mathrm{PO}_{4}, 4 \mathrm{mM}\right.$ $\mathrm{NaHCO}_{3}, 1.3 \mathrm{mM} \mathrm{CaCl}_{2}, 0.8 \mathrm{mM} \mathrm{MgSO}_{4}$, and $0.5 \mathrm{mM} \mathrm{MgCl}_{2}$ with $10 \mathrm{mM}$ glucose) containing $5 \mu \mathrm{M}$ Fura-2/AM for $30 \mathrm{~min}$ at $37^{\circ} \mathrm{C}$. After two times wash with similar saline, the coverslip was perfused with the saline solution, and recordings were made at 340 and $380 \mathrm{~nm}$ excitation and $510 \mathrm{~nm}$ emission wavelengths at $15 \mathrm{~s}$ intervals. The data are presented as 340/380 ratio $\mathrm{R}$ normalized to $340 / 380$ ratio reading at the rest $\left(\mathrm{R}_{0}\right)$. The SOCE was assessed by measuring the amplitude of $\left[\mathrm{Ca}^{2+}\right]_{i}$ transient induced by re-addition of extracellular $\mathrm{Ca}^{2+}$ to cells pre-incubated with $\mathrm{Ca}^{2+}$-free buffer in combination with the SERCA inhibitor thapsigargin. Twenty cells were selected in each coverslip, and three coverslips were averaged in each experimental group.

\section{Materials}

Chemicals for preparation of culturing medium were purchased from Sigma (St. Louis, MO, USA) and horse serum from Invitrogen (Carlsbad, CA, USA). Most chemicals, including CBZ, VPA, 4-CML (4-chloro-3-methylphenol) and thapsigargin were purchased from Sigma (St. Louis, MO, USA). Lithium carbonate $\left(\mathrm{Li}_{2} \mathrm{CO}_{3}\right)$ was obtained from Shanghai Hengxin Chemical Reagent (Shanghai, China). TRPC1 antibody (ACC010) was obtained from Alomone Labs (Jerusalem, Israel). Antibody specific to $\beta$-actin (A5441) was obtained from Sigma-Aldrich (St. Louis, MO, USA). Goat-anti-rabbit IgG HRP conjugate was obtained from Santa Cruz Biotechnology (Santa Cruz, CA, USA). Goat-anti-mouse IgG HRP conjugate 
A
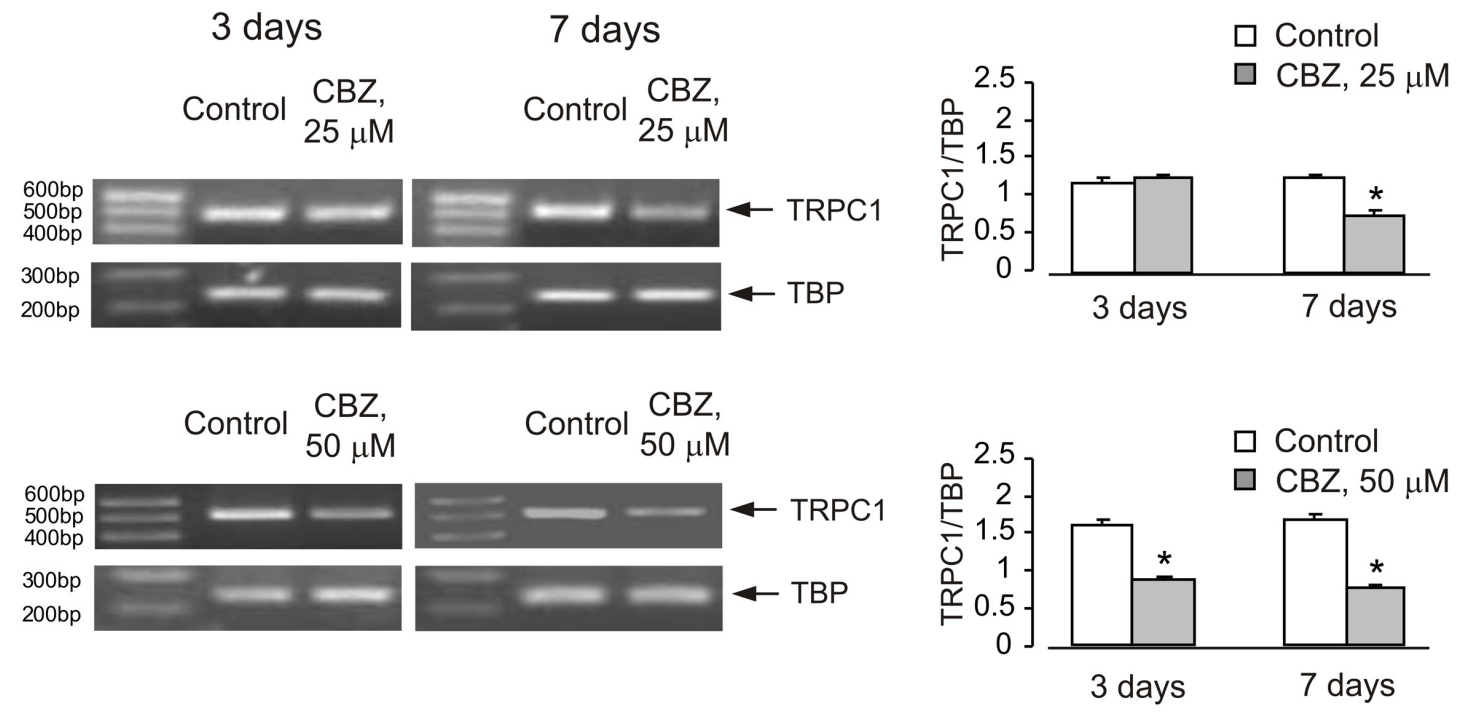

B

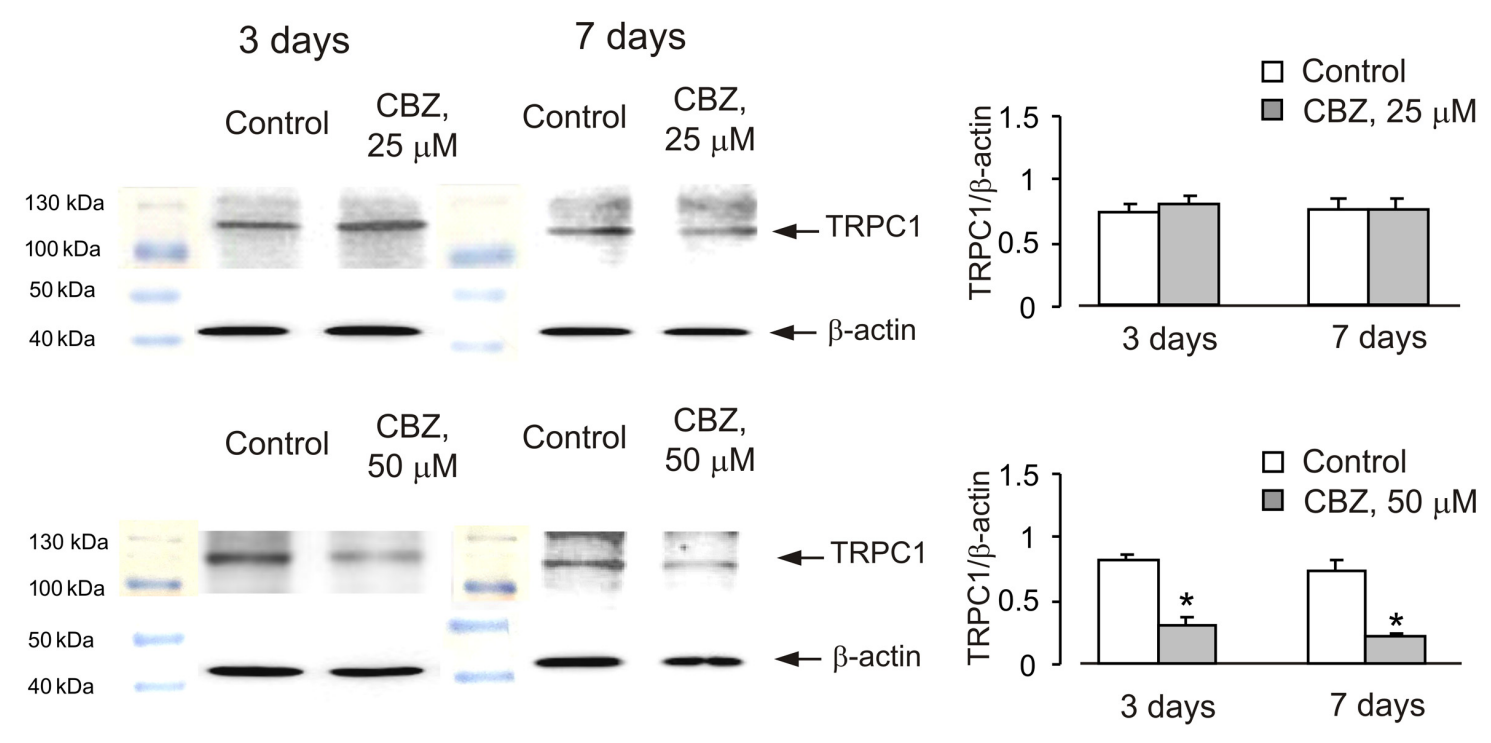

FIGURE 1 | Down-regulation of mRNA and protein expression of TRPC1 by chronic treatment with carbamazepine (CBZ) in primary cultures of mouse cerebellar granule cells. Cells were treated with PBS (control) or with 25 or $50 \mu \mathrm{M}$ CBZ for 3 or for 7 days. (A) Southern blot from a representative experiment. Similar results were obtained from three independent experiments. Average mRNA expression was quantified as a ratio between TRPC1 and TBP, as a housekeeping gene. The size of the PCR product of TRPC1 is $517 \mathrm{bp}$ and that of TBP $236 \mathrm{bp}$. SEM values are indicated by vertical bars. *Statistically significant $(p<0.05)$ difference from control group. (B) Immunoblot from a representative experiments. Similar results were obtained from three independent experiments. Average protein expression was quantified as a ratio between TRPC1 and $\beta$-actin. SEM values are indicated by vertical bars. *Statistically significant $(p<0.05)$ difference from control group.

was obtained from Promega (Madison, WI, USA). Fura2 AM was obtained from Invitrogen (Carlsbad, CA, USA). Random Hexamer and Taq-polymerase for RT-PCR were purchased from TaKaRa Biotechnology, Co., Ltd (Dalian, China).

\section{Statistics}

All statistical comparisons between groups were performed by Student's $t$-test. Levels of significance were expressed as $P$-values.

\section{RESULTS}

\section{Gene Expression of TRPC1}

Chronic treatment of cultured cerebellar granule neurones with CBZ decreased mRNA and protein expression of TRPC1 in a time- and concentration-dependent manner (Figure 1). Seven days of treatment with $\mathrm{CBZ}$ at $25 \mu \mathrm{M}$ down-regulated of mRNA expression of TRPC1 whereas 3 days of treatment had no effect. However, CBZ at $50 \mu \mathrm{M}$ caused a significant down-regulation 
A
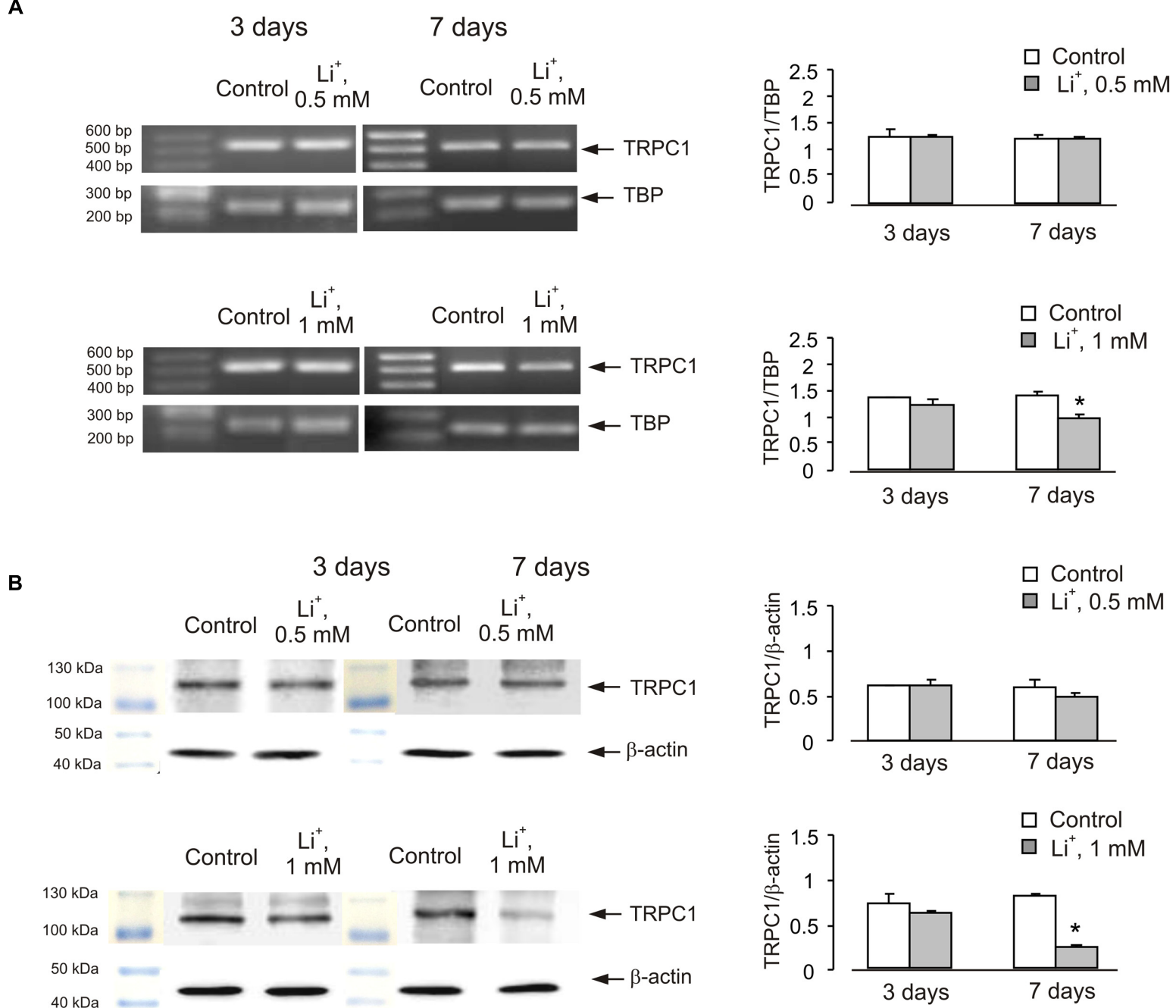

FIGURE 2 | Down-regulation of mRNA and protein expression of TRPC1 by chronic treatment with lithium in primary cultures of mouse cerebellar granule cells. Cells were treated with PBS (control) or with 0.5 or $1 \mathrm{mM}$ lithium for 3 or 7 days. (A) Southern blot from a representative experiment. Similar results were obtained from three independent experiments. Average mRNA expression was quantified as a ratio between TRPC1 and TBP, as a housekeeping gene. The size of the PCR product of TRPC1 is $517 \mathrm{bp}$ and that of TBP $236 \mathrm{bp}$. SEM values are indicated by vertical bars. *Statistically significant ( $p<0.05)$ difference from control group. (B) Immunoblot from a representative experiments. Similar results were obtained from three independent experiments. Average protein expression was quantified as a ratio between TRPC1 and $\beta$-actin. SEM values are indicated by vertical bars. ${ }^{*}$ Statistically significant $(p<0.05)$ difference from control group.

of TRPC1 mRNA after 3 days $(54 \pm 4.1 \%)$ with further decline after 7 days $[45 \pm 4.6 \%$ of control group (Figure 1A)]. Protein expression of TRPC1 was unaffected by both 3 and 7 days of treatment with $25 \mu \mathrm{M} \mathrm{CBZ}$, but after 3 or 7 days of treatment with $50 \mu \mathrm{M}$ CBZ it decreased significantly to $37 \pm 9.1$ and $30 \pm 3.9 \%$, respectively when compared to the control group (Figure 1B; originals of blots are presented in Supplementary Figure S1).

Similar effect was also observed in cells treated with lithium carbonate or VPA (Figures 2 and 3). Exposure to $0.5 \mathrm{mM}$ $\mathrm{Li}^{+}$did not affect TRPC1 expression neither after 3 nor after 7 days, whereas a decrease in expression to $61 \pm 3.4 \%$ of control group was observed at $1 \mathrm{mM} \mathrm{Li}^{+}$after 7 days (Figure 2A). Protein expression of TRPC1 has not changed after 3 as well as after 7 days of treatment with $0.5 \mathrm{mM} \mathrm{Li}^{+}$. However, after
7 days of treatment with $1 \mathrm{mM} \mathrm{Li}^{+}$, protein expression of TRPC1 significantly decreased to $31 \pm 6.9 \%$ compared to control (Figure 2B). Similarly, exposure to $100 \mu \mathrm{M}$ VPA had no effect, whereas in the presence of $1 \mathrm{mM}$ VPA, mRNA expression of TRPC1 decreased to $55 \pm 5.5$ and $51 \pm 5.8 \%$ of control group after 3 and 7 days, respectively (Figure 3A). The TRPC1 protein was similarly down-regulated in the presence of $1 \mathrm{mM}$ VPA after 3 days to $40 \pm 8.3 \%$ of control group and after 7 days to $39 \pm 4.1 \%$ of control group, although no effect was detected at $100 \mu \mathrm{M}$ of VPA after 3 and 7 days (Figure 3B).

In order to see whether the effect of anti-bipolar drugs is restricted to cerebellar granule cells, we analyzed the effect of CBZ, lithium carbonate or VPA on TRPC1 gene expression in cultured cerebral cortical neurones. Treatment of cultured 


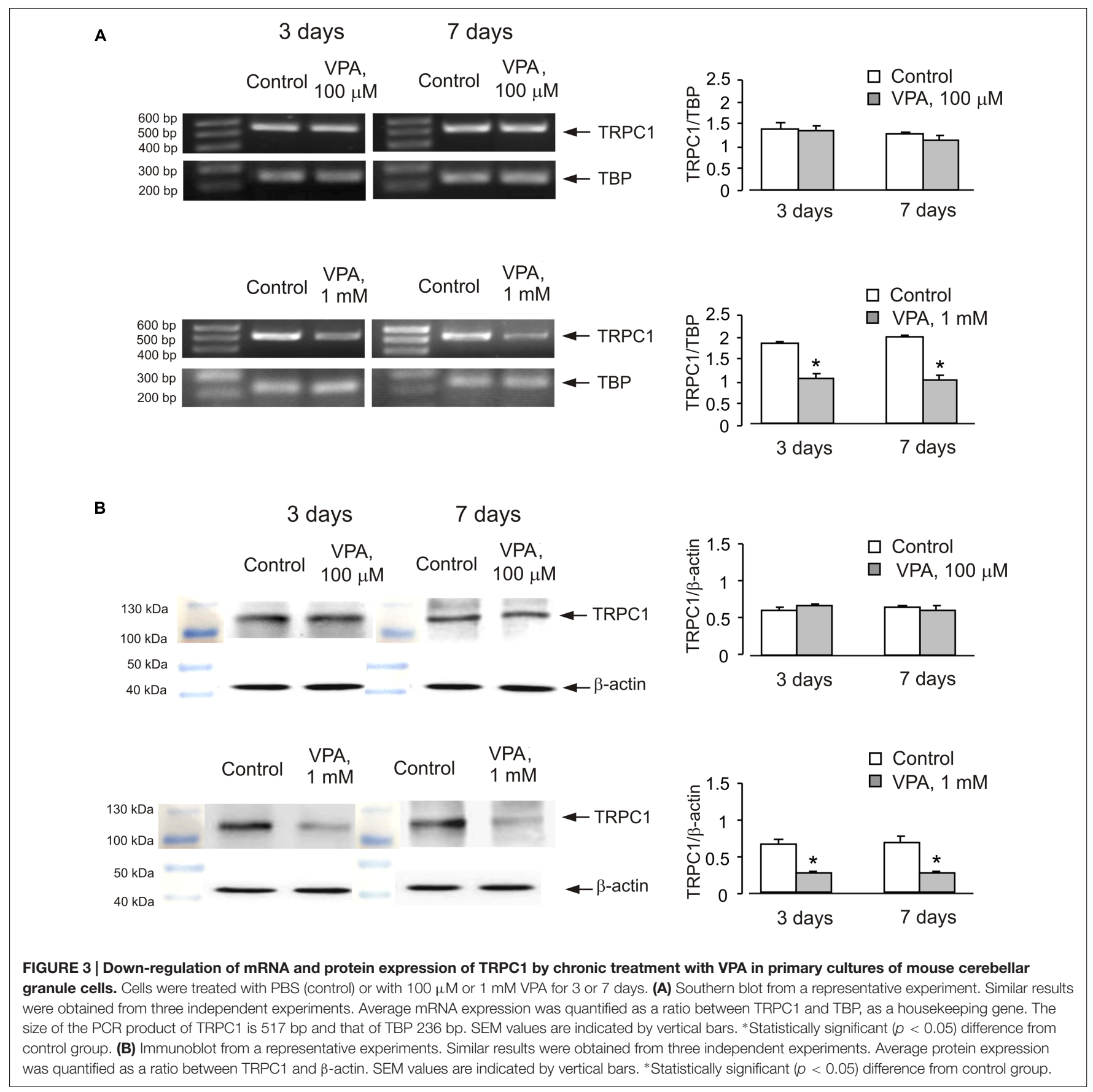

cerebral cortical neurones with $50 \mu \mathrm{M}$ CBZ induced a decrease of TRPC1 mRNA expression to $57 \pm 2.1$ and $47 \pm 2.0 \%$ of control group after 3 and 7 days, respectively. Protein expression of TRPC1 similarly decreased to $39 \pm 1.8$ and $35 \pm 2.5 \%$ compared to control after 3 and 7 days of treatment (Figure 4A). Exposure to $1 \mathrm{mM}$ lithium carbonate decreased TRPC1 mRNA expression to $68 \pm 2.1 \%$ of control group after 7 days. Protein expression of TRPC1 similarly decreased to $47 \pm 3.5 \%$ compared to control after 7 days of treatment (Figure 4B). Treatment with $1 \mathrm{mM} \mathrm{VPA}$ decreased TRPC 1 mRNA expression to $51 \pm 1.6$ and $49 \pm 2.2 \%$ of control group after 3 and 7 days, respectively. Protein expression of TRPC1 was similarly decreased to $47 \pm 7.6$ and $32 \pm 5.8 \%$ compared to control after 3 and 7 days of treatment (Figure 4C). In addition, comparable decrease in TRPC1 mRNA expression was observed in neurones freshly isolated from the brains of CBZ treated mice; mRNA was decreased to $61 \pm 5.2$ and $52 \pm 2.0 \%$ of control group after 3 and 7 days, respectively (Figure 5).

\section{Store-Operated $\mathrm{Ca}^{2+}$ Entry}

The decrease of TRPC1 gene expression in cerebellar granule cells chronically treated with $\mathrm{CBZ}$ was associated with the decrease in the amplitude of SOCE (Figure 6A). To analyze the SOCE 
A

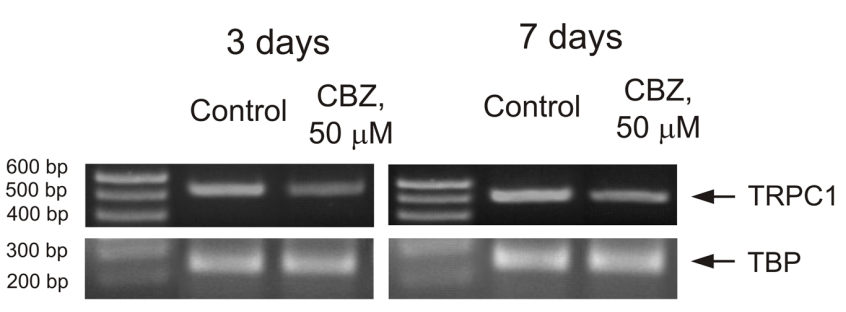

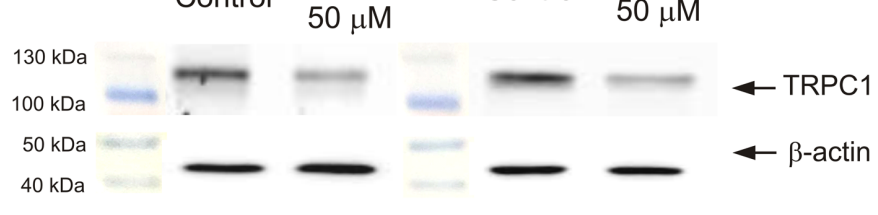

3 days $\quad 7$ days
B

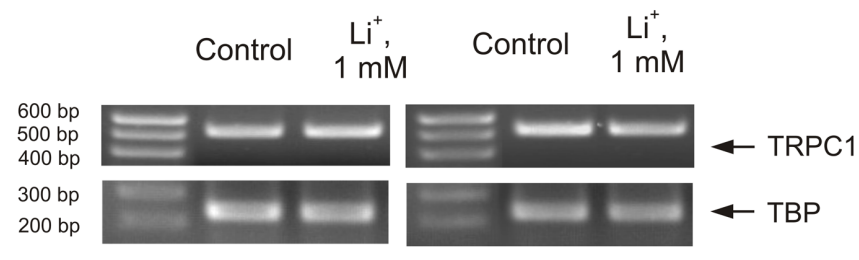

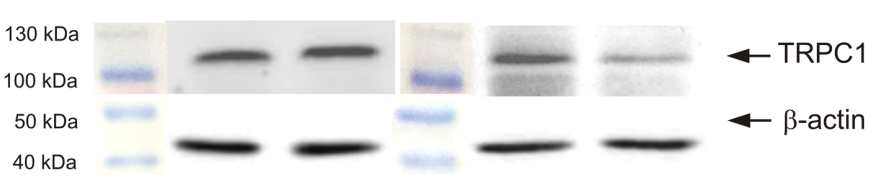

3 days

C

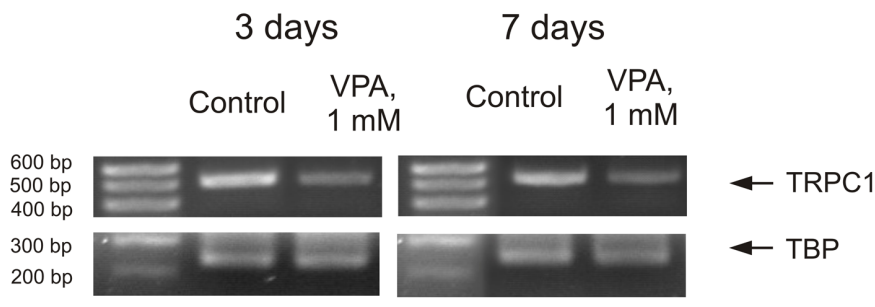

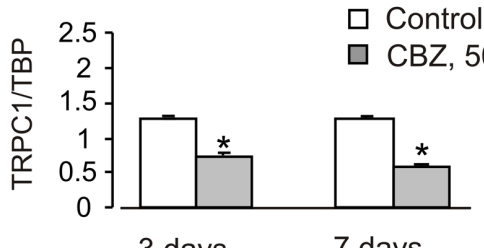

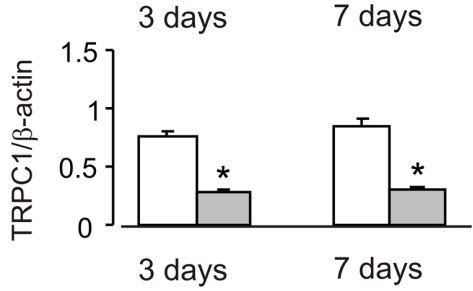

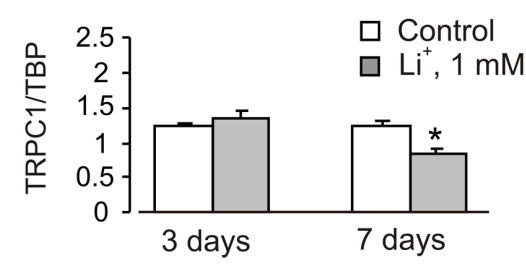
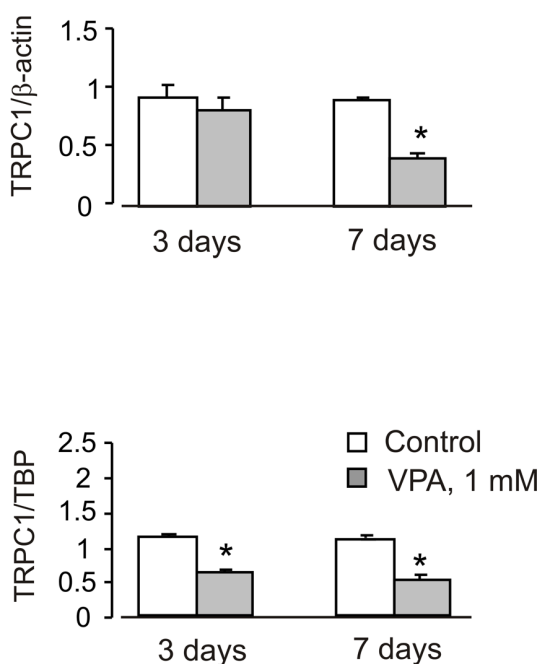

$\begin{array}{ll}\text { Control } & \text { VPA, } \\ 1 \mathrm{mM}\end{array} \quad$ Control $\begin{array}{r}\text { VPA, } \\ 1 \mathrm{mM}\end{array}$
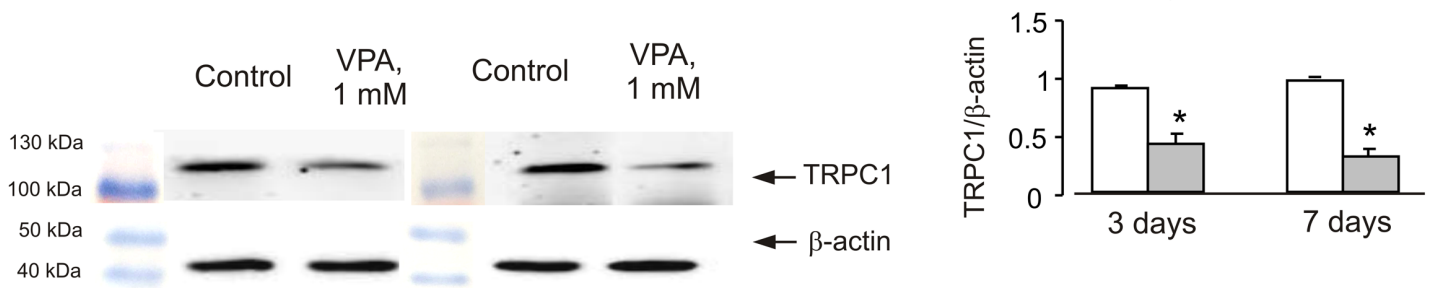

FIGURE 4 | Down-regulation of mRNA and protein expression of TRPC1 by chronic treatment with CBZ, Li ${ }^{+}$, or VPA in primary cultures of mouse cerebral cortical neuron. (A) Cells were treated with PBS (control) or with $50 \mu \mathrm{M} \mathrm{CBZ} \mathrm{for} 3$ or 7 days. (B) Cells were treated with PBS (control) or with1 mM Li+ for 3 or 7 days. (C) Cells were treated with PBS (control) or with 1 mM VPA for 3 or 7 days. The representative Southern blot and immunoblot are shown. Similar results were obtained from three independent experiments. Average mRNA expression was quantified as a ratio between TRPC1 and TBP, as a housekeeping gene. The size of the PCR product of TRPC1 is $517 \mathrm{bp}$ and that of TBP $236 \mathrm{bp}$. Average protein expression was quantified as ratios between TRPC1 and $\beta$-actin. SEM values are indicated by vertical bars. *Statistically significant $(p<0.05)$ difference from control group. 

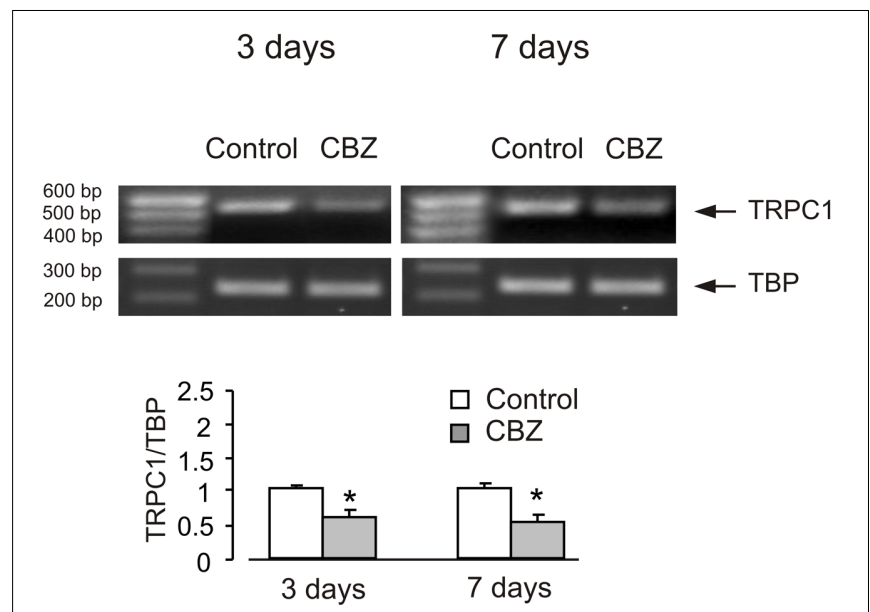

FIGURE 5 | CBZ induced down-regulation of mRNA and protein expression of TRPC1 in neurones isolated by FACS from cerebral hemisphere in vivo from mice. Adult [B6.Cg-Tg(Thy1-YFPH)2Jrs/J] mice were treated with either saline (control) or CBZ (25 mg/kg/day) dissolved in saline for 3 or 7 days. Average mRNA expression was quantified as a ratio between TRPC1 and TBP, as a housekeeping gene. The size of the PCR product of TRPC1 is $517 \mathrm{bp}$ and that of TBP $236 \mathrm{bp}$. Similar results were obtained from three independent experiments. SEM values are indicated by vertical bars. ${ }^{*}$ Statistically significant $(p<0.05)$ difference from control group.

cells were incubated in $\mathrm{Ca}^{2+}$-free buffer with $1 \mu \mathrm{M}$ thapsigargin for $10 \mathrm{~min}$. Thereafter $\mathrm{Ca}^{2+}(2 \mathrm{mM})$ was re-introduced into the incubation buffer, this triggering $\left[\mathrm{Ca}^{2+}\right]_{\mathrm{i}}$ transient mediated by the SOCE pathway. Of note, the SOCE was not affected by inhibitors of voltage-gated $\mathrm{Ca}^{2+}$ channels (Supplementary Figure S2), indicating that SOCE-associated cell depolarisation did not exceed the threshold of $\mathrm{Ca}^{2+}$ channels activation. The amplitude of $\left[\mathrm{Ca}^{2+}\right]_{\mathrm{i}}$ transient associated with SOCE decreased by $\sim 55 \%$ ( $0.1894 \pm 0.0290$ in control vs. $0.0857 \pm 0.0228$ in CBZ treated cells, $n=60, p<0.05$ ) after 3 days and by $\sim 58 \%$ $(0.3217 \pm 0.0394$ in control vs. $0.1361 \pm 0.0313$ in CBZ treated cells, $n=60, p<0.05$ ) after 7 days of treatment with $50 \mu \mathrm{M}$ CBZ (Figure 6A). Treatment with $1 \mathrm{mM} \mathrm{Li}^{+}$for 3 days had no effect on SOCE, after 7 days, however. SOCE decreased by $55 \%\left(0.2367 \pm 0.0283\right.$ in control vs. $0.1055 \pm 0.0255$ in $\mathrm{Li}^{+}$ treated cells, $n=60, p<0.05$ ) (Figure 6B). The amplitude of $\left[\mathrm{Ca}^{2+}\right]_{\mathrm{i}}$ transient associated with SOCE decreased by $\sim 64 \%$ $(0.2479 \pm 0.0205$ in control vs. $0.0899 \pm 0.0188$ in VPA treated cells, $n=60, p<0.05$ ) after 3 days and by $\sim 57 \%$ $(0.2367 \pm 0.0283$ in control vs. $0.1008 \pm 0.0263$ in VPA treated cells, $n=60, p<0.05)$ after 7 days of treatment with $1 \mathrm{mM}$ VPA (Figure 6C). In both control and drug-treated cells, $\left[\mathrm{Ca}^{2+}\right]_{\mathrm{i}}$ elevation induced by the SERCA inhibitor thapsigargin at $1 \mu \mathrm{M}$ was not detectable.

\section{DISCUSSION}

A large body of evidence indicates that the resting and stimulated levels of $\left[\mathrm{Ca}^{2+}\right]_{\mathrm{i}}$ are elevated in BD (Wasserman et al., 2004 and references therein). It has been noted also that several mood stabilizers affect intracellular $\mathrm{Ca}^{2+}$ dynamics in various neuronal cells. For example, CBZ inhibits NMDA-evoked $\mathrm{Ca}^{2+}$ influx in rat cerebellar granule cells (Hough et al., 1996), while long-term $\mathrm{Li}^{+}$treatment attenuates NMDA receptormediated $\mathrm{Ca}^{2+}$ entry in primary cultures of rat cerebellar granule cells (Nonaka et al., 1998) and glutamate-mediated $\mathrm{Ca}^{2+}$ signaling in hippocampal neurones (Sourial-Bassillious et al., 2009). Significant reduction of the low-threshold $\mathrm{Ca}^{2+}$ current has been observed in rat nodose neurones treated with valproic acid (Kelly et al., 1990). Our present findings suggest that down-regulation of TRPC1 gene expression may be one of the mechanisms of drug action on intracellular $\mathrm{Ca}^{2+}$ dynamics in neurones.

Firstly, we found that chronic treatment with all three antibipolar drugs, CBZ, $\mathrm{Li}^{+}$and VPA, down-regulated mRNA and protein expression of TRPC1 in a concentration-dependent manner. CBZ at lower concentration $(25 \mu \mathrm{M})$ decreased TRPC1 gene expression after 7 days of treatment but had no effect after 3 days of treatment. However, both $\mathrm{Li}^{+}$and VPA at lower concentrations $(0.5 \mathrm{mM}$ and $100 \mu \mathrm{M})$ had no effect in the time period used in the present study. This effect of drugs seems to be independent from the type of neurones. In the present work, we have observed the decrease of TRPC1 expression in cultured cerebellar granule cells, cultured cerebral cortical neurones and freshly isolated neurones from the brains in vivo. Previously, we reported similar drug effect in astrocytes (Yan et al., 2013). Secondly, we found a substantial decrease in the SOCE in cerebellar granule cells exposed to each of the three drugs. TRPC1 channels control several aspects of cytosolic ion signaling due to their polyionic permeability, as in physiological conditions TRPC1 channels provide both $\mathrm{Ca}^{2+}$ and $\mathrm{Na}^{+}$influx (Reyes et al., 2013). In astrocytes, the TRPC1 protein has been implicated in exocytotic release of glutamate (Parpura et al., 2011).

It has been suggested that TRPC1 are positioned downstream of glutamate metabotropic receptors (mGluRs) and NMDA receptors in neurones. It is of interest because overactivity of glutamatergic system in BD has been documented (Chen et al., 2010), and regulation of TRPC1 function by glutamate receptors may contribute to the pathophysiology of the disease. It has been reported that TRPC1 channels localize in perisynaptic regions of the cerebellar parallel fiber-Purkinje cell synapse where they are physically and functionally coupled with the mGluR1 to induce a slow excitatory post-synaptic conductance (EPSC) (Kim et al., 2003). Knocking down TRPC1 using TRPC1-shRNA or blocking TRPC1 channels reduced glutamate-induced and mGluR5-mediated cell death in murine hippocampal cell line HT22 (Narayanan et al., 2014). The large depolarizing plateau potential which is essential for the epileptiform burst firing by metabotropic glutamate receptors was reduced by $74 \%$ in septal neurones of $\mathrm{TRPC}^{-/-}$mice compared to WT mice (Phelan et al., 2012). In olfactory bulb granule cells TRPC1, as well as TRPC4, can be activated downstream of NMDA receptors and contribute to slow dendritic GABA release (Stroh et al., 2012). These findings suggest that TRPC1 contributes to multiple signals instigated by activation of glutamate receptors, and a decrease of TRPC1 expression and function by anti-bipolar 
A
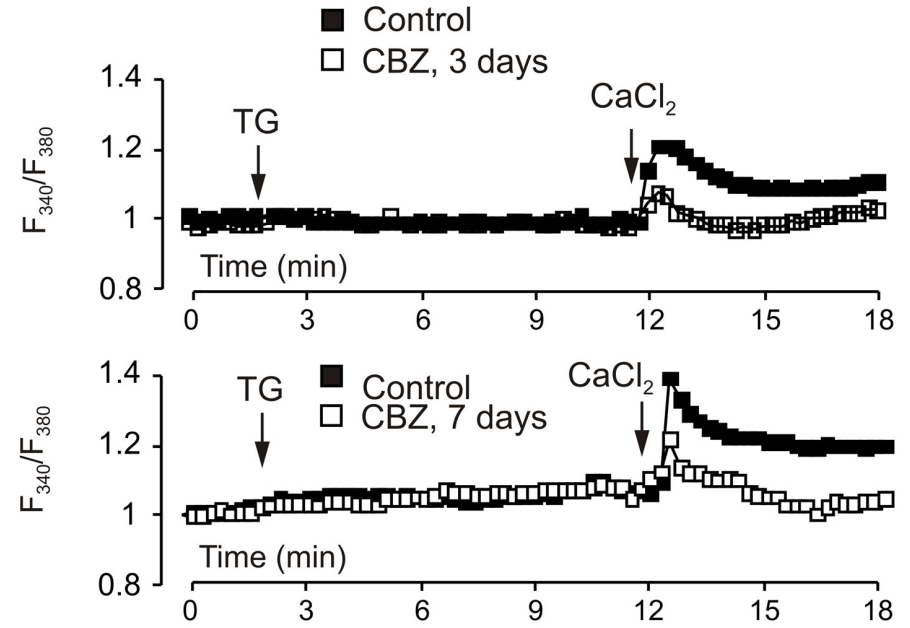

B
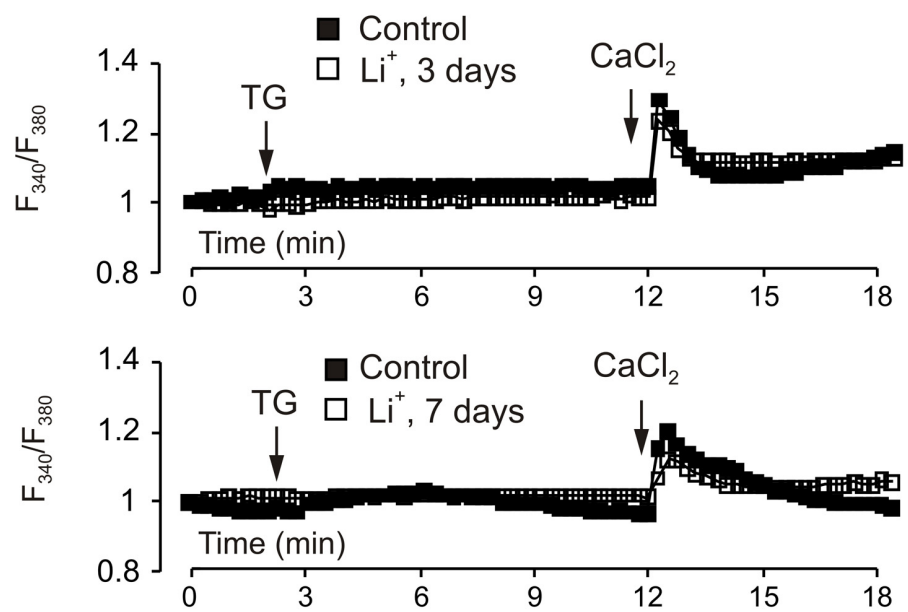

C
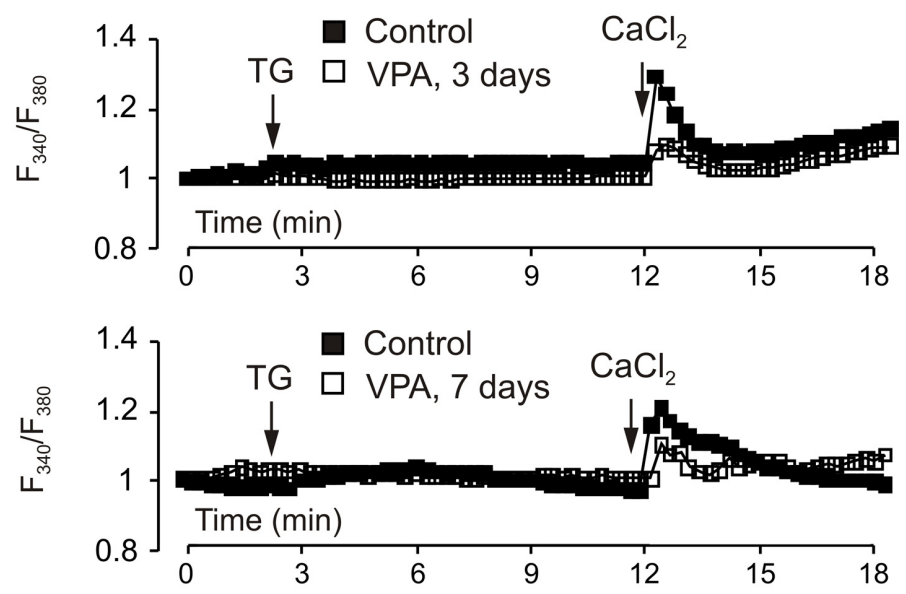
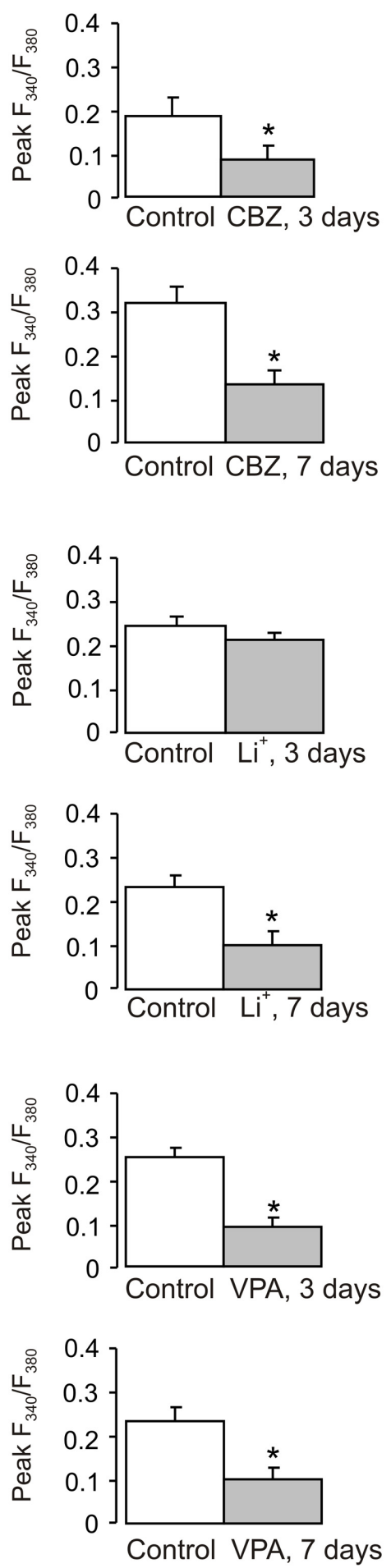

FIGURE 6 | Effect of chronic treatment with CBZ, lithium or VPA on store-operated $\mathrm{Ca}^{2+}$ entry in primary cultures of mouse cerebellar granule cells. Cells were treated with CBZ $(50 \mu \mathrm{M})$, lithium $(1 \mathrm{mM})$, or VPA $(1 \mathrm{mM})$ for 3 or 7 days. After loading with fura- 2 AM for 30 min, cells were incubated in Ca ${ }^{2+}$-free buffer with $1 \mu \mathrm{M}$ thapsigargin, an inhibitor of SERCAs. After 10 min $\mathrm{Ca}^{2+}(2 \mathrm{mM})$ was re-introduced into the incubation buffer. (A-C) Representative traces show the averaged changes in $\left[\mathrm{Ca}^{2+}\right]_{i}$ (normalized with the $\mathrm{R} / \mathrm{R}_{0}$ ratio at the 0 time; each representative trace shows the average changes in $\left[\text { Ca }{ }^{2+}\right]_{i}$ of three individual experiments; 20 cells per experiment). Mean of peak amplitudes of SOCE-associated $\left[\mathrm{Ca}^{2+}\right]_{i}$ peak. SEM values are indicated by vertical bars. *Shows statistically significant $(p<0.05)$ difference from control group. 
drugs may overcome of the abnormal overactivity of glutamate receptors that develops in $\mathrm{BD}$.

\section{CONCLUSION}

We demonstrated, for the first time, that gene expression of neuronal TRPC1 is decreased by all three anti-bipolar drugs. Keeping in mind the similar effect in astrocytes, we may conceive that TRPC1 may be a new therapeutic target for BD. It seems that the decrease of TRPC1 gene expression and function affects multiple neurotransmitters in neuronal cells. However, the final conclusion of the pathophysiological relevance depends on further understanding of TRPC1 function in neurones.

\section{ETHICS STATEMENT}

All experiments were carried out in accordance with the USA National Institute of Health Guide for the Care and Use of Laboratory Animals (NIH Publications No. 80-23) revised 1978, and all experimental protocols were approved by the Institutional Animal Care and Use Committee of China Medical University.

\section{REFERENCES}

Bak, L. K., Schousboe, A., and Waagepetersen, H. S. (2003). Characterization of depolarization-coupled release of glutamate from cultured mouse cerebellar granule cells using DL-threo-beta-benzyloxyaspartate (DL-TBOA) to distinguish between the vesicular and cytoplasmic pools. Neurochem. Int. 43, 417-424. doi: 10.1016/S0197-0186(03)00030-5

Chen, G., Henter, I. D., and Manji, H. K. (2010). Presynaptic glutamatergic dysfunction in bipolar disorder. Biol. Psychiatry 67, 1007-1009. doi: 10.1016/ j.biopsych.2010.03.027

Chuang, D. M., Chen, R. W., Chalecka-Franaszek, E., Ren, M., Hashimoto, R., Senatorov, V., et al. (2002). Neuroprotective effects of lithium in cultured cells and animal models of diseases. Bipolar Disord. 4, 129-136. doi: 10.1034/j.13995618.2002.01179.x

Condorelli, D. F., Dell'Albani, P., Aronica, E., Genazzani, A. A., Casabona, G., Corsaro, M., et al. (1993). Growth conditions differentially regulate the expression of alpha-amino-3-hydroxy-5-methylisoxazole-4-propionate (AMPA) receptor subunits in cultured neurons. J. Neurochem. 61, 2133-2139. doi: 10.1111/j.1471-4159.1993.tb07451.x

el-Marjou, A., Delouvee, A., Thiery, J. P., and Radvanyi, F. (2000). Involvement of epidermal growth factor receptor in chemically induced mouse bladder tumour progression. Carcinogenesis 21, 2211-2218. doi: 10.1093/carcin/21.12.2211

Feng, G., Mellor, R. H., Bernstein, M., Keller-Peck, C., Nguyen, Q. T., Wallace, M., et al. (2000). Imaging neuronal subsets in transgenic mice expressing multiple spectral variants of GFP. Neuron 28, 41-51. doi: 10.1016/S0896-6273(00) 00084-2

Fu, H., Li, B., Hertz, L., and Peng, L. (2012). Contributions in astrocytes of SMIT1/2 and HMIT to myo-inositol uptake at different concentrations and $\mathrm{pH}$. Neurochem. Int. 61, 187-194. doi: 10.1016/j.neuint.2012.04.010

Gallo, V., Kingsbury, A., Balazs, R., and Jørgensen, O. S. (1987). The role of depolarization in the survival and differentiation of cerebellar granule cells in culture. J. Neurosci. 7, 2203-2213.

Goodwin, F. K., and Jamison, K. R. (2007). Manic-Depressive Illness: Bipolar Disorders and Recurrent Depression. New York, NY: Oxford University Press.

Hertz, E., Yu, A. C. H., Hertz, L., Juurlink, B. H. J., and Schousboe, A. (1989). "Preparation of primary cultures of mouse cortical neurons," in A Dissection and Tissue Culture Manual for the Nervous System, eds A. Shahar, J. de Vellis, A. Vernadakis, and B. Haber (New York, NY: Alan R. Liss), 183-186.

\section{AUTHOR CONTRIBUTIONS}

LP conceived and designed experiments; TD, YR, and RF collected and analyzed the data; LP and AV interpreted the data and wrote the paper. All authors commented on the manuscript and have approved the final version.

\section{ACKNOWLEDGMENT}

This study was supported by No. 31300883 to TD from the National Natural Science Foundation of China.

\section{SUPPLEMENTARY MATERIAL}

The Supplementary Material for this article can be found online at: http://journal.frontiersin.org/article/10.3389/fncel. 2016.00305/full\#supplementary-material

\section{FIGURE S1 | Original blots of Figure 1B.}

FIGURE S2 | Nifedipine, a blocker of L-type calcium channels did not affect SOCE administered either $1 \mathrm{~min}$ after addition of $\mathrm{Ca}^{2+}(\mathrm{A})$ or $2 \mathrm{~min}$ before addition of TG (B).

Hough, C. J., Irwin, R. P., Gao, X. M., Rogawski, M. A., and Chuang, D. M. (1996). Carbamazepine inhibition of N-methyl-D-aspartate-evoked calcium influx in rat cerebellar granule cells. J. Pharmacol. Exp. Ther. 276, 143-149.

Kelly, K. M., Gross, R. A., and Macdonald, R. L. (1990). Valproic acid selectively reduces the low-threshold (T) calcium current in rat nodose neurons. Neurosci. Lett. 116, 233-238. doi: 10.1016/0304-3940(90)90416-7

Kim, S. J., Kim, Y. S., Yuan, J. P., Petralia, R. S., Worley, P. F., and Linden, D. J. (2003). Activation of the TRPC1 cation channel by metabotropic glutamate receptor mGluR1. Nature 426, 285-291. doi: 10.1038/nature02162

Kong, E. K., Peng, L., Chen, Y., Yu, A. C., and Hertz, L. (2002). Up-regulation of 5-HT2B receptor density and receptor-mediated glycogenolysis in mouse astrocytes by long-term fluoxetine administration. Neurochem. Res. 27, 113120. doi: 10.1023/A:1014862808126

Lavreysen, H., Willemoens, T., Leysen, J. E., and Lesage, A. S. (2005). Antagonistinduced supersensitivity of mGlul receptor signalling in cerebellar granule cells. Eur. J. Neurosci. 21, 1610-1616. doi: 10.1111/j.1460-9568.2005.03998.x

Li, B., Gu, L., Zhang, H., Huang, J., Chen, Y., Hertz, L., et al. (2007). Up-regulation of cPLA(2) gene expression in astrocytes by all three conventional anti-bipolar drugs is drug-specific and enzyme-specific. Psychopharmacology (Berl) 194, 333-345. doi: 10.1007/s00213-007-0853-5

Li, B., Zhang, S., Li, M., Zhang, H., Hertz, L., and Peng, L. (2009). Down-regulation of GluK2 kainate receptor expression by chronic treatment with moodstabilizing anti-convulsants or lithium in cultured astrocytes and brain, but not in neurons. Neuropharmacology 57, 375-385. doi: 10.1016/j.neuropharm.2009. 07.004

Li, M., Chen, C., Zhou, Z., Xu, S., and Yu, Z. (2012). A TRPC1-mediated increase in store-operated $\mathrm{Ca}^{2+}$ entry is required for the proliferation of adult hippocampal neural progenitor cells. Cell Calcium 51, 486-496. doi: 10.1016/j.ceca.2012.04. 014

Lovatt, D., Sonnewald, U., Waagepetersen, H. S., Schousboe, A., He, W., Lin, J. H., et al. (2007). The transcriptome and metabolic gene signature of protoplasmic astrocytes in the adult murine cortex. J. Neurosci. 27, 12255-12266. doi: 10. 1523/JNEUROSCI.3404-07.2007

Lowry, O. H., Rosebrough, N. J., Farr, A. L., and Randall, R. J. (1951). Protein measurement with the Folin phenol reagent. J. Biol. Chem. 193, 265-275.

Marini, A. M., Schwartz, J. P., and Kopin, I. J. (1989). The neurotoxicity of 1methyl-4-phenylpyridinium in cultured cerebellar granule cells. J. Neurosci. 9, 3665-3672. 
Martorana, A., Giampa, C., DeMarch, Z., Viscomi, M. T., Patassini, S., Sancesario, G., et al. (2006). Distribution of TRPC1 receptors in dendrites of rat substantia nigra: a confocal and electron microscopy study. Eur. J. Neurosci. 24, 732-738. doi: 10.1111/j.1460-9568.2006.04932.x

Narayanan, K. L., Irmady, K., Subramaniam, S., Unsicker, K., and von Bohlen und Halbach, O. (2008). Evidence that TRPC1 is involved in hippocampal glutamate-induced cell death. Neurosci. Lett. 446, 117-122. doi: 10.1016/j. neulet.2008.09.034

Narayanan, K. L., Subramaniam, S., Bengston, C. P., Irmady, K., Unsicker, K., and von Bohlen und Halbach, O. (2014). Role of transient receptor potential channel 1 (TRPC1) in glutamate-induced cell death in the hippocampal cell line HT22. J. Mol. Neurosci. 52, 425-433. doi: 10.1007/s12031-013-0171-9

Ng, L. C., McCormack, M. D., Airey, J. A., Singer, C. A., Keller, P. S., Shen, X. M., et al. (2009). TRPC1 and STIM1 mediate capacitative $\mathrm{Ca}^{2+}$ entry in mouse pulmonary arterial smooth muscle cells. J. Physiol. 587, 2429-2442. doi: 10.1113/jphysiol.2009.172254

Nonaka, S., Hough, C. J., and Chuang, D. M. (1998). Chronic lithium treatment robustly protects neurons in the central nervous system against excitotoxicity by inhibiting N-methyl-D-aspartate receptor-mediated calcium influx. Proc. Natl. Acad. Sci. U.S.A. 95, 2642-2647. doi: 10.1073/pnas.95.5.2642

Parpura, V., Grubišić, V., and Verkhratsky, A. (2011). $\mathrm{Ca}^{2+}$ sources for the exocytotic release of glutamate from astrocytes. Biochim. Biophys. Acta 1813, 984-991. doi: 10.1016/j.bbamcr.2010.11.006

Peng, L., Juurlink, B. H. J., and Hertz, L. (1991). Differences in transmitter release, morphology, and ischemia-induced cell injury between cerebellar granule cell cultures developing in the presence and in the absence of a depolarizing potassium concentration. Dev. Brain Res. 63, 1-12. doi: 10.1016/0165-3806(91) 90061-M

Peng, L., Li, B., and Verkhratsky, A. (2016). Targeting astrocytes in bipolar disorder. Expert Rev. Neurother. 16, 649-657. doi: 10.1586/14737175.2016.1171144

Phelan, K. D., Mock, M. M., Kretz, O., Shwe, U. T., Kozhemyakin, M., Greenfield, L. J., et al. (2012). Heteromeric canonical transient receptor potential 1 and 4 channels play a critical role in epileptiform burst firing and seizure-induced neurodegeneration. Mol. Pharmacol. 81, 384-392. doi: 10.1124/mol.111. 075341

Rao, J. S., Bazinet, R. P., Rapoport, S. I., and Lee, H. J. (2007). Chronic administration of carbamazepine down-regulates AP-2 DNA-binding activity and AP-2alpha protein expression in rat frontal cortex. Biol. Psychiatry 61, 154-161. doi: 10.1016/j.biopsych.2006.03.029

Reyes, R. C., Verkhratsky, A., and Parpura, V. (2013). TRPC1-mediated $\mathrm{Ca}^{2+}$ and $\mathrm{Na}^{+}$signalling in astroglia: differential filtering of extracellular cations. Cell Calcium 54, 120-125. doi: 10.1016/j.ceca.2013.05.005
Riccio, A., Medhurst, A. D., Mattei, C., Kelsell, R. E., Calver, A. R., Randall, A. D., et al. (2002). mRNA distribution analysis of human TRPC family in CNS and peripheral tissues. Brain Res. Mol. Brain Res. 109, 95-104. doi: 10.1016/S0169328X(02)00527-2

Schousboe, A., and Hertz, L. (1987). "Primary cultures of GABAergic and glutamatergic neurons as model systems to study neurotransmitter functions. II. Developmental aspects," in Model Systems of Development and Aging of the Nervous System, eds A. Vernadakis, A. Privat, J. M. Lauder, P. S. Timiras, and E. Giacobini (Boston, MA: Martinus Nijhoff Publishers), 33-42.

Seki, M., Nawa, H., Morioka, T., Fukuchi, T., Oite, T., Abe, H., et al. (2002). Establishment of a novel enzyme-linked immunosorbent assay for Thy-1; quantitative assessment of neuronal degeneration. Neurosci. Lett. 329, 185-188. doi: 10.1016/S0304-3940(02)00654-7

Sourial-Bassillious, N., Rydelius, P. A., Aperia, A., and Aizman, O. (2009). Glutamate-mediated calcium signaling: a potential target for lithium action. Neuroscience 161, 1126-1134. doi: 10.1016/j.neuroscience.2009.04.013

Stroh, O., Freichel, M., Kretz, O., Birnbaumer, L., Hartmann, J., and Egger, V. (2012). NMDA receptor-dependent synaptic activation of TRPC channels in olfactory bulb granule cells. J. Neurosci. 32, 5737-5746. doi: 10.1523/ JNEUROSCI.3753-11.2012

Vennekens, R., Menigoz, A., and Nilius, B. (2012). TRPs in the Brain. Rev. Physiol. Biochem. Pharmacol. 163, 27-64. doi: 10.1007/112_2012_8

Wasserman, M. J., Corson, T. W., Sibony, D., Cooke, R. G., Parikh, S. V., Pennefather, P. S., et al. (2004). Chronic lithium treatment attenuates intracellular calcium mobilization. Neuropsychopharmacology 29, 759-769. doi: 10.1038/sj.npp.1300400

Yan, E., Li, B., Gu, L., Hertz, L., and Peng, L. (2013). Mechanisms for L-channelmediated increase in $\left[\mathrm{Ca}^{2+}\right] \mathrm{i}$ and its reduction by anti-bipolar drugs in cultured astrocytes combined with its mRNA expression in freshly isolated cells support the importance of astrocytic L-channels. Cell Calcium 54, 335-342. doi: 10. 1016/j.ceca.2013.08.002

Conflict of Interest Statement: The authors declare that the research was conducted in the absence of any commercial or financial relationships that could be construed as a potential conflict of interest.

Copyright (C) 2017 Du, Rong, Feng, Verkhratsky and Peng. This is an open-access article distributed under the terms of the Creative Commons Attribution License (CC BY). The use, distribution or reproduction in other forums is permitted, provided the original author(s) or licensor are credited and that the original publication in this journal is cited, in accordance with accepted academic practice. No use, distribution or reproduction is permitted which does not comply with these terms. 